where it was once productive. Many other developing countries have never benefited in this way. The moral for them is that priority should be given to the development of agricultural research. The other leaf that should be taken from the Indian book is the demonstration of competence in the pursuit of science, if only so that too much talent is not lost too soon.

\section{Powell bites dust}

\section{The British government needs to think hard} now about surrogacy.

THE British government has done the decent (and courageous) thing by deciding that it will not lift a finger to save Mr Enoch Powell's bill on in vitro fertilization from being lost in the procedural hazards of the House of Commons (see p. 573). Common sense requires that there should be an opportunity to consider carefully how research in this field should be regulated. That regulation of some kind is necessary is agreed by everybody, even those who work in laboratories, but there are serious doubts whether the 14-day limit suggested by the Warnock committee is either appropriate or workable. It is to be hoped that the government will now consider seriously whether regulation by public ethical committee would be preferable, not least as a way of meeting the public concern that research with living human embryos should be responsibly designed and soberly directed. That course will not comfort those (Mr Powell included) who hold that the whole idea is an abomination. That is the sense in which the government has shown courage - and is the reason why prudence again requires that it should press ahead with its own legislation as quickly as it can.

To take the edge off the complaints there will be when the Powell bill is defeated next month, the government plans that there will be an outright ban on what is called commercial surrogacy, the practice by which healthy women offer the service of gestation to others for a fee. Warnock would have banned all surrogacy, but an important minority opinion on the committee held that some allowance should be made for exceptional circumstances. The plain truth, now, is that nobody knows how common may be the practice in countries such as Britain, and there is only guesswork to suggest what may be the circumstances (apart from the infertility of the intended mother). Yet reports abound of women providing this service for infertile sisters, while there is no way of knowing what small proportion of illegitimate births followed by adoption are essentially surrogacy arrangements.

That is one reason why the outright ban on "commercial" surrogacy now proposed deserves more careful consideration. In the spirit of the present time, which rightly allows an adopted child to learn something about its natural parents at majority, frankness about genetic origins is in fashion (and could, sometimes, be medically important in tracking genetic defects). Should these principles not also apply to children born of surrogacy in the forms now accepted? Will such practices, tacitly condoned at present, become crimes if the surrogate mother is rewarded in kind, not cash? And what is to happen if the small but unavoidable risks of pregnancy to the mother should become realities? Do her dependants go neglected? These questions may be hypothetical, but they are also important.

The British government has started from the other end of the problem - the publicity and the attendant fuss following a surrogate birth last year in which a commercial agency had been involved. Would the fuss have been as great if the agency had been a registered charity, organized perhaps as if it were an adoption agency? Almost certainly not. This is but one reason why the British government should be prepared to allow for exceptions to the rule it is now planning to introduce. The guiding principles should be that surrogacy should not be allowed to make anybody's fortune but that women who volunteer to provide the service should be safeguarded and repaid for their time and trouble, preferably in a manner open to public scrutiny. Is that too much to ask?

\section{International manners}

The US administration should not offend its

\section{friends overseas by tactlessness.}

NEXT month's meeting of the heads of government of the major industrialized nations, to be held at Bonn in West Germany, has all the makings of a rough-house. On this occasion, the hard core of the agenda, economics, will be the chief reason why the United States will find itself pinned uncomfortably in a corner. But US policy on strategic arms is likely also to sour what people have to say to President Ronald Reagan. Continuing doubt over US intentions over its star wars plans is one bone of contention. Italian President Bettino Craxi was right to complain last week that the US administration owed Mr Mikhail Gorbachev a less ungracious reply to the Soviet of fer to suspend the deployment of SS20 missiles aimed at Europe than the jaundiced comment that it was a mere propaganda ploy.

The substance of these issues has been much debated, here and elsewhere, but the manner in which the United States now conducts its international business is becoming an obstacle to its attainment of its objectives. Even those who agree with what the administration is trying to achieve must be dismayed. $\mathrm{Mr}$ Gorbachev, after all, declared that the Soviet Union would unilaterally halt the deployment of SS20 missiles within range of Western Europe until November, and would continue a moratorium thereafter if mutual agreement was reached by then. The proposal is full of snags, while the plan to make it public at this stage is a breach of the agreement between the superpowers to restrict their negotiations on strategic arms to the closed sessions at Geneva. But even a thoroughly sceptical administration could have contented itself with something like "High time!" or "There'll be time to talk about that at Geneva". Last week's needlessly hard lines will have made many third parties ask who are the bad guys now.

Much the same is true of the US administration's public statements on the international money problem. In the past few days, US cabinet officers have too quickly taken up President Reagan's cry last month that there would be no imbalance in the world economy if only European states were as productive as the United States, which is at best a half-truth and which may even be more false than true. (If Europe were as productive as it might be, the United States would not be able to fund its present deficit by borrowing from abroad except by pushing interest rates still higher.) The irony in this is that the United States seems not to have been restrained in its attempts to correct its trade balance with the most productive of its international competitors, Japan. But the proposal now being canvassed by officials in Washington that would-be US exporters should be represented on the regulatory committees that will deregulate the supply of equipment to the Japanese telephone system will seem especially demeaning in Japan, where it will be recognized that the proposal would be constitutionally impossible in many places, and in Europe, where it will be asked why only US exporters should enjoy this privilege.

Complaints such as these that the United States too often behaves as if its own interests are paramount are not new. Most people also acknowledge that the United States has a special role in world affairs, militarily and economically. The sympathetic among them also appreciate the difficulty of a government such as that of the United States, with huge domestic preoccupations and watched over by a necessarily parochial Congress, in finding forms of words to explain itself that do not raise hackles elsewhere. Yet the administration's performance seems to be getting worse.

Part of the trouble may be the number of new faces, or of old faces in new jobs, that have made their appearance at the White House and in US government agencies since the beginning of the year. That is the charitable explanation, in which case Bonn may be a stimulus for changing tack and for learning that international relations are as easily soured as personal relations by tactlessness. Let us hope the explanation is not more sinister. 